\title{
Termite assemblages (Blattaria, Isoptera) in two montane forest (Brejo de Altitude) areas in northeastern Brazil
}

\author{
Israel Soares da Silva ${ }^{1,2}$, Alexandre Vasconcellos ${ }^{2 *}{ }^{\mathbb{D}}$ \& Flávia Maria da Silva Moura $^{1}$ \\ ${ }^{1}$ Universidade Federal de Campina Grande, Centro de Saúde e Tecnologia Rural, Unidade Acadêmica de \\ Ciências Biológicas, Patos, PB, Brasil \\ ${ }^{2}$ Universidade Federal da Paraíba, Centro de Ciências Exatas e da Natureza, Departamento de Sistemática e \\ Ecologia, Laboratório de Termitologia, João Pessoa, PB, Brasil
}

"Corresponding author: Alexandre Vasconcellos, e-mail: alextermites@gmail.com

SILVA, I. S., VASCONCELlOS, A., MOURA, F. M. S. Termite assemblages (Blattaria, Isoptera) in two montane forest (Brejo de Altitude) areas in northeastern Brazil. Biota Neotropica. 19(1): e20180519. http:// dx.doi.org/10.1590/1676-0611-BN-2018-0519

\begin{abstract}
Wet enclaves of montane forests in Caatinga domain, locally known as "Brejos de Altitude", are associated with plateau at altitudes greater than $500 \mathrm{~m}$ a.s.l. and to orographic rainfall. Termite assemblage structures were studied in two areas of montane forest (Brejo de Altitude) located in the municipalities of Bezerros and São Vicente Ferrer, Pernambuco State, Brazil. Sampling was performed in $65 \times 2 \mathrm{~m}$ transects, totaling $300 \mathrm{~m}^{2} /$ per area; the densities of nests in each area were estimated using six $1300 \mathrm{~m}^{2}$ plots. A total of 35 morphospecies were recorded that belonged to 21 genera and three families, with 133 encounters. The soil-feeders feeding group predominated, followed by wood-feeders species. A total of five species constructing conspicuous nest were recorded in the two areas. The mean density of active conspicuous nests was $2.6 \pm 6.3$ nests/ha (mean $\pm \mathrm{sd}$ ) in Bezerros, and $21.8 \pm 21.4$ nests/ha in São Vicente Ferrer. Termite richness in the study areas were within the amplitude ranges recorded in other montane forests. Thus, the results presented here, combined with data from literature, reinforce need additional studies of the termite fauna in montane forest areas, once the "Brejos" are currently under high ecological pressure and their preservation is urgent.
\end{abstract}

Keywords: Biodiversity, feeding groups, nest density, Acorhinotermes, Neotropical region.

\section{Taxocenoses de térmitas (Blattaria, Isoptera) em duas florestas de altitude (Brejo de Altitude) no nordeste do Brasil}

Resumo: Enclaves de floresta úmida de altitude nos domínios da Caatinga, localmente conhecidos como "Brejos de Altitude", estão associados a áreas com mais de $500 \mathrm{~m}$ de altitude e às chuvas orográficas. O presente estudo teve como objetivo caracterizar a estrutura da taxocenose de térmitas em duas áreas de Brejo de Altitude localizadas nos municípios de Bezerros e São Vicente Ferrer, Estado do Pernambuco, Brasil. A amostragem foi realizada através de transectos de $65 \mathrm{~m} \mathrm{x} 2 \mathrm{~m}$, totalizando $300 \mathrm{~m}^{2} /$ por área. Em cada área, a densidade de ninhos foi estimada em seis parcelas de $1300 \mathrm{~m}^{2}$. Trinta e cinco morfoespécies foram registradas nas duas áreas, pertencentes a 21 gêneros e três famílias, com 133 encontros. O grupo alimentar dos humívoros foi predominante, seguido pelos xilófagos. Um total de cinco espécies construtoras de ninhos conspícuos foram registradas nas duas áreas. A densidade média de ninhos conspícuos ativos foi de 2,6 \pm 6,3 ninhos/ha (média $\pm \mathrm{dp}$ ) em Bezerros, e de 21,8 \pm 21,4 ninhos/ha em São Vicente Ferrer. A riqueza de térmitas das áreas estudadas ficou dentro da amplitude já registrada para áreas de Brejo de Altitude. Assim, os resultados aqui apresentados, combinados com dados da literatura, reforçam a necessidade de estudos adicionais da fauna de térmitas em áreas de floresta montana, uma vez que os Brejos estão atualmente sob alta pressão ecológica e sua preservação é urgente.

Palavras-chave: Biodiversidade, grupos alimentares, densidade de ninhos, Acorhinotermes, Região Neotropical. 


\section{Introduction}

The Caatinga domain is a mosaic of spiny shrubs and seasonally dry tropical forests covering approximately $735,000 \mathrm{~km}^{2}$ in northeastern Brazil (Leal et al. 2005). The Caatinga domain is bordered by the Atlantic Forest to the east, the Amazon Forest to the west, and Cerrado (neotropical savanna) to the south (Leal et al. 2005, Prado 2003), and it harbors enclaves of humid montane forests locally known "Brejos de Altitude" or "Brejos Nordestinos" (Andrade-Lima, 1982). The origin of these mountains has been associated with climatic shifts during the Pleistocene, with the current forest enclaves representing the results of expansion and retraction cycles of more humid forests within the dryer Caatinga matrix (Andrade-Lima 1982, Santos et al. 2007).

Montane forests are associated with plateaus at altitudes greater than $500 \mathrm{~m}$ a.s.l. and orographic rainfall with precipitation levels above $1200 \mathrm{~mm} /$ year (Andrade-Lima 1960, Veloso et al. 1991, Tabarelli \& Santos 2004), with perennial, sub-perennial, and sub-deciduous forests predominating on the highest slopes (Andrade-Lima 1966, AndradeLima 2007). When compared to adjacent semiarid regions, those montane forests show milder temperatures and higher humidity levels (Andrade-Lima 1966, Rodal \& Sales, 2008). Studies focusing on the phylogeography of anuran amphibians (Carnaval, 2002; Carnaval \& Bates, 2007), reptile distributions (Borges-Nojosa \& Caramaschi, 2003), arboreal physiognomy and diversity (Tavares et al., 2000; Rodal \& Sales, 2008), and parsimony analyses of woody plant endemism (Santos et al., 2007) have all indicated that the areas have a biota with distinct characteristics between them. These forests have high rates of endemism (Andrade-Lima, 1982), biological communities little known (Silva et al. 2018), and there is a strong degradation of the original formation, being considered currently priority areas for the conservation of the biodiversity (Prado 2003; Silva et al. 2018).

Termites are eusocial insects of the infraorder Isoptera (order Blattaria) that have important functions in the dynamic ecological processes of nutrient recycling, soil aeration, and the maintenance of soil fertility (Wood \& Sands 1978, Holt \& Lepage 2000), and their activities are principally associated with benefits to primary production (Bignell \& Eggleton 2000). Termite distribution is predominately tropical, with humid equatorial forests and savannas having the greatest species richness, abundance, and biomass; diversity declines with increasing latitude and altitude (Eggleton 2000, Jones \& Eggleton 2011, Cancello et al. 2014; Nunes et al., 2017).

Termite fauna of montane forests have been investigated in six different areas, generating species lists (Vasconcellos \& Moura 2014, Couto et al. 2015) and studies of the influence of anthropogenic disturbances on termite assemblages (Bandeira \& Vasconcellos 2002, Bandeira et al. 2003, Bandeira \& Vasconcellos 2004) and their vertical stratification (Araújo et al. 2015). The present study sought to characterize the structures of termite assemblages in two montane forest areas in northeastern Brazil in terms of their species richness, relative abundance, feeding groups, and nest densities.

\section{Materials and Methods}

\section{Study area}

The present study was undertaken in two areas of montane forest in northeastern Brazil: i) Mata Vertentes (BEZ) in the municipality of Bezerros, Pernambuco State, Brazil (8¹1'12"S x 3547’29”W); ii) the Mata do Estado Municipal Reserve (SVF) in the municipality of São Vicente Ferrer, Pernambuco State, Brazil (7³7'07'S x 35030'15”W) (Figure 1). The Mata Vertentes comprises an area of 129 ha at approximately $960 \mathrm{~m}$ a.s.1. The climate there is tropical rainy, usually with dry summers (KÖppen 1936, Alvares et al. 2013); the mean annual rainfall is $442.5 \mathrm{~mm}$ (APAC 2017), with a mean annual temperature of $22.9{ }^{\circ} \mathrm{C}$ (DCA 2016). The Mata do Estado Municipal Reserve comprises an area of 600 ha, at approximately $570 \mathrm{~m}$ a.s.l., with a rainy tropical climate with dry summers (KÖppen 1936, Alvares et al. 2013), a mean annual rainfall rate of 928.7 mm (APAC 2017), and mean annual temperatures between $22^{\circ} \mathrm{C}$ and $26^{\circ} \mathrm{C}$ (SEMAS 2014). The vegetation of the studied areas is perennial, formed by fragments of montane rain forests. Due to anthropogenic disturbances, vegetation varies from primary forests to highly impacted secondary forests (Veloso \& Góes Filho 1982; Andrade-Lima 2007).

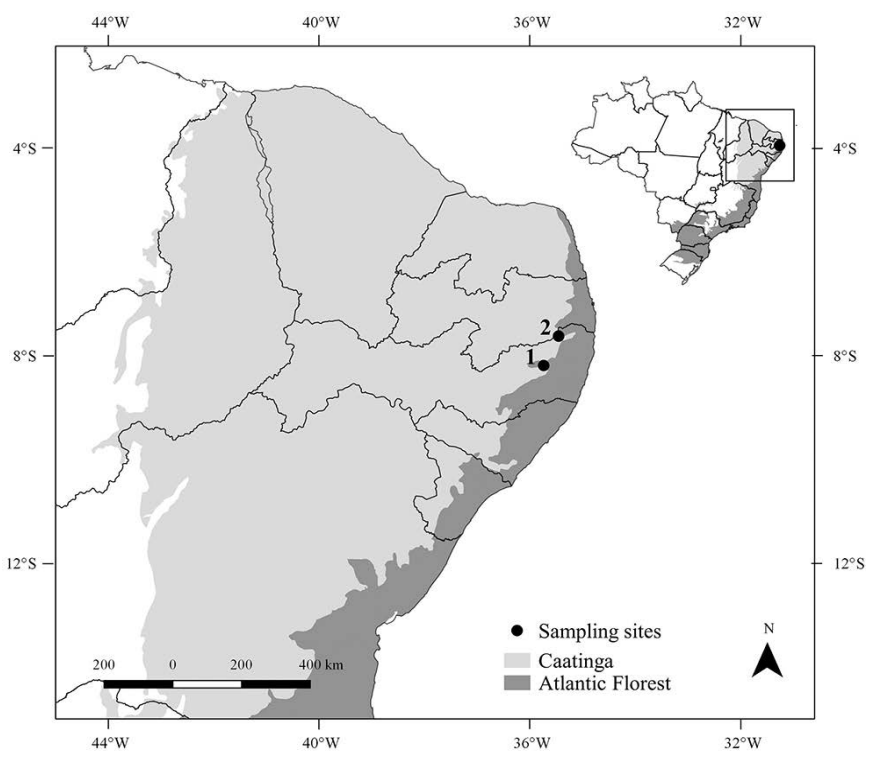

Figure 1. Locations of the study areas in northeastern Brazil. (1) Mata Vertentes, municipality of Bezerros, Pernambuco State, Brazil (2) Mata do Estado Municipal Reserve, municipality of São Vicente Ferrer, Pernambuco State, Brazil.

\section{Sampling protocols}

The termite assemblages were sampled between April and July/2017 using protocols based on transect sampling (modified from De Souza \& Brown [1994] and Jones \& Eggleton [2000]) similar to those described by Cancello et al. (2014). Six $65 \mathrm{~m}$ x $2 \mathrm{~m}$ transects (separated one from the other by at least $200 \mathrm{~m}$ ) were established in each locality. Each transect was subdivided into five $5 \times 2 \mathrm{~m}$ plots every $10 \mathrm{~m}$, totaling 30 plots $\left(300 \mathrm{~m}^{2}\right)$ per locality. The sampling effort in each plot was 1 hour-person. We searched for termites in active and abandoned nests (up to $2 \mathrm{~m}$ above the ground), in tunnels, in the trunks of live and dead trees, in the leaf litter, inside the fallen tree boughs, beneath the ground (up to $15 \mathrm{~cm}$ below the surface), under stones, and within dead roots. The specimens collected were stored in flasks containing $80 \%$ alcohol and subsequently deposited in the Isoptera Collection at the Federal University of Paraíba. 


\section{Species determination}

The genera were determined using taxonomic keys present in Constantino (2002) and Bourguignon et al. (2016). At the species level were used the descriptions listed in Constantino (1998; 2017). All the material was compared with the species housed in the Entomological Collection of the Termitology Laboratory/LabTermes of the Federal University of Paraíba, Brazil.

\section{Feeding groups}

Feeding group assignments were based on in situ observations and information available in the specialized literature concerning neotropical termites (De Souza \& Brown 1994, Constantino 1999, Bandeira et al. 2003, Sena et al. 2003, Vasconcellos et al. 2005, Cancello et al. 2014). The species were classified as belonging to the following feeding groups (FG1): (i) woodfeeders, those that consume the wood of living trees, or of dead trees in various stages of decomposition; (ii) soil-feeders, those that feed on humus and generally live in the soil; (iii) wood/soil-feeders, those that consume humus, as well as wood in different stages of decomposition and generally transport soil to within the wood they are consuming; and (iv) wood/leaf-feeders, those that consume wood in advanced stages of decomposition, as well as leaves gathered on the forest floor. The termites were also categorized following the proposals of Donovan et al. (2001) (see Table 1, FG2).

\section{Nest densities}

In each area, the densities of conspicuous nests were estimated within six $65 \times 20 \mathrm{~m}$ plots established parallel to the transects used in the faunal inventory. All nests with volumes $\geq 2.0 \mathrm{~L}$ in those plots were identified, counted, and characterized as: (i) arboreal, nests constructed on the trunks and branches of living or dead trees; (ii) epigeal, nests generally initiated below ground level, but eventually growing and emerging with an above-ground portion.

\section{Analyses}

The number of plots in which a given species was present (encounters) was used as an indirect measure of relative abundance (Jones 2000).
Species accumulation curves were constructed using the Mao Tau method, considering $95 \%$ confidence intervals for 1000 randomizations without replacement of the original data. Chao 2 non-parametric estimator was used to evaluate species richness in each area. Those analyses were performed using EstimateS 9.1.0 software (Colwell 2017).

\section{Results}

A total of 35 termite species were recorded in the two study areas, of which 19 (54\%) were identified and 16 (46\%) were morphotyped; they belonged to 21 genera and three families, with 133 encounters (Table 1). The family Termitidae comprised the greatest numbers of species $(80.0 \%)$ and encounters $(93.2 \%)$, Rhinotermitidae comprised $11.4 \%$ of the species and $3.0 \%$ of the encounters, while Kalotermitidae comprised $8.6 \%$ of the species and $3.8 \%$ of the encounters.

Fifteen termite morphospecies were encountered in Bezerros, belonging to 12 genera and three families, with 54 encounters. São Vicente Ferrer had a richness of 24 morphospecies belonging to 14 genera and three families, with 79 encounters. The most abundant species in Bezerros was Nasutitermes corniger (Motschulsky, 1855) (14 encounters), and the two most abundant species in São Vicente Ferrer were Apicotermitinae sp.4 and Diversitermes diversimiles (Silvestri, 1901) (12 and 9 encounters respectively) (Table 1).

In relation to the subfamilies of Termitidae, the subfamily Apicotermitinae had the greatest species richness ( 6 species; $50.0 \%)$ and numbers of encounters (26 encounters; 53.1\%) in Bezerros, while the subfamily Nasutitermitinae had the greatest number of species $(9 ; 45 \%)$ and number of encounters (38; 50.1\%) in São Vicente Ferrer (Figure 2).

The estimated species richness in Bezerros was 16.16 0.32 (mean \pm standard error) (Chao2), and the estimated species richness in São Vicente Ferrer was $50.58 \pm 4.03$ (Chao2). The species accumulation curve in Bezerros had a slight tendency towards attaining its asymptote; the accumulation curve in São Vicente Ferrer had an ascending tendency. According to the confidence intervals, there were no significant differences between the species accumulation curves of the two areas (Figure 3).
A

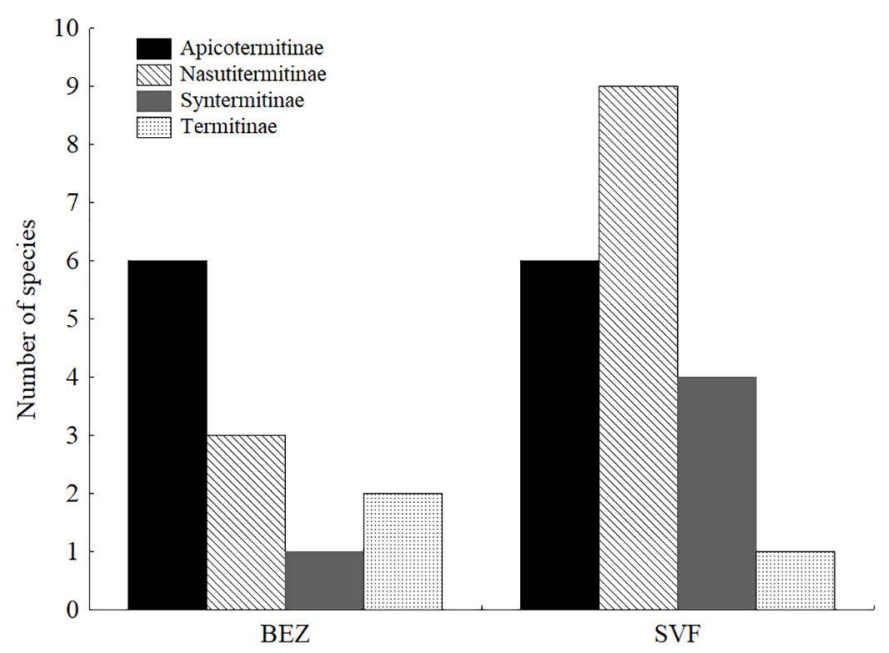

B

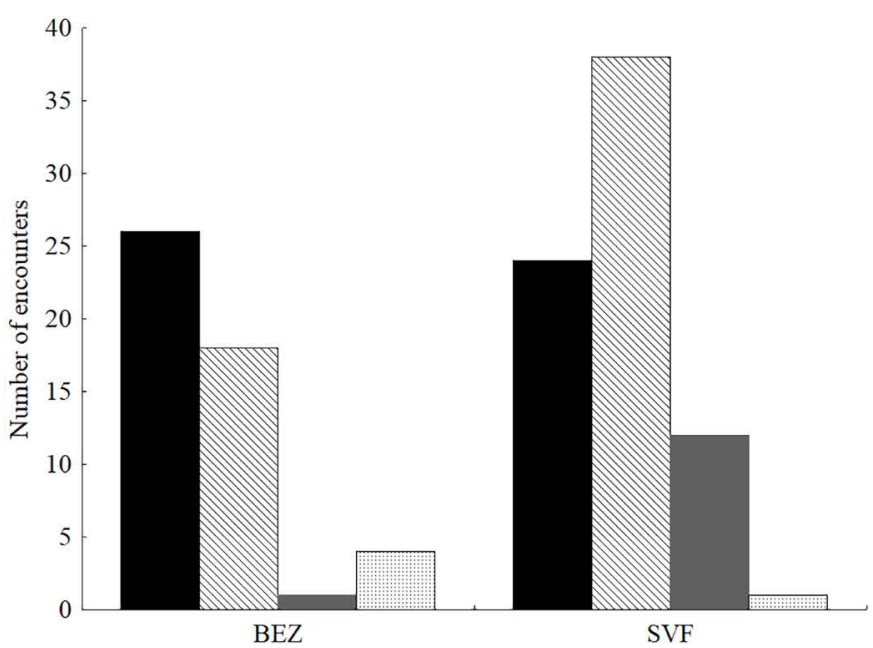

Figure 2. Species richness (a) and numbers of encounters (b) of termites per subfamily of Termitidae in the municipalities of Bezerros (BEZ) and São Vicente Ferrer (SVF), Pernambuco State, Brazil. 
Silva, I. S. et al.

Table 1. Species richness, relative abundances (numbers of encounters), feeding group, and micro-habitats of termites in the study areas in the municipalities of Bezerros (BEZ) and São Vicente Ferrer (SVF), Pernambuco State, Brazil. Micro-habitat: Li, leaf litter; Wo, wood; Ne, nest; So, soil. FG: feeding groups. FG1: W, wood-feeders; S, soil-feeders; W/L, wood/leaf-feeders; W/S, wood/soil-feeders. FG2: following the categories of Donovan et al. (2001). * Conspicuous nest.

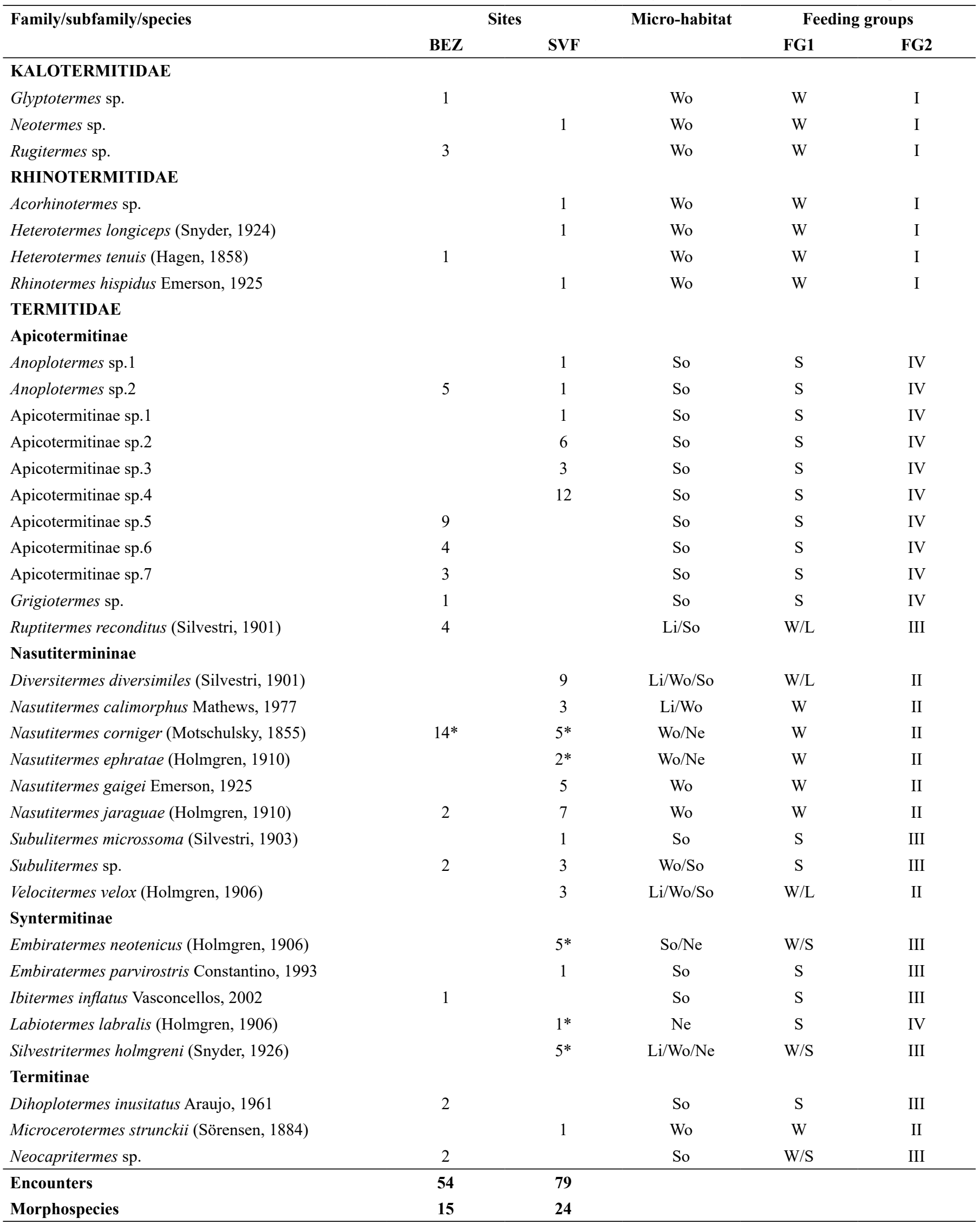




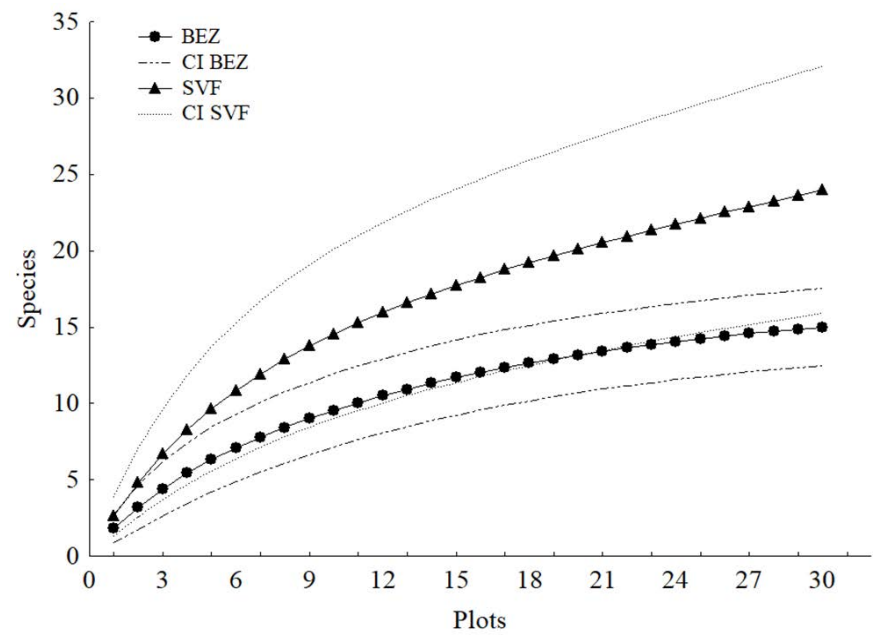

Figure 3. Accumulation curves of termite species (Mao Tau), and 95\% confidence intervals $(\mathrm{CI})$.

The soil-feeders (FG1) were predominant in Bezerros, representing $53.3 \%$ of the species and $50.0 \%$ of the encounters; the second most predominant feeding group was wood-feeders. There were equal numbers of soil-feeders and wood-feeders termite species $(41.7 \%$ each) in São Vicente Ferrer, with the soil-feeders demonstrating the greatest numbers of encounters (38.0\%) (Figure 4). According to the classification of Donovan et al. (2001), feeding groups III and IV demonstrated the greatest numbers of species in Bezerros (33.3\% each), while group II (33.3\%) and group IV (29.2\%) had the greatest numbers of species in São Vicente Ferrer (Table 1, FG2).

The mean nest density in Bezerros was $2.6 \pm 6.3$ (mean \pm standard deviation) active nests/ha, with Nasutitermes corniger being the only termite that built conspicuous nests, while the mean nest density in São Vicente Ferrer was $21.8 \pm 21.4$ active nests/ha. Four arboreal nest building species were encountered in the latter area: Labiotermes labralis (Holmgren, 1906) (2.6 \pm 6.3 active nests/ha), Nasutitermes corniger (3.8 \pm 6.4 ), Nasutitermes ephratae (Holmgren, 1910) (5.1 \pm 6.3 ), and Silvestritermes holmgreni (Snyder, 1926) (2.6 \pm 4.0$)$.
Embiratermes neotenicus (Holmgren, 1906) was the only species recorded in the study that constructed epigeal nests, with a density of $7.7 \pm 6.9$ active nests/ha in São Vicente Ferrer.

\section{Discussion}

A total 35 species were found, of which 19(54\%) were identified and 16 (46\%) were morphotyped. The species Rhinotermes hispidus, Nasutitermes gaigei, and Velocitermes velox represent new records for montane forests. Including those three new records, approximately 48 species have now been identified to the species level in eight inventoried montane forests (Bandeira \& Vasconcellos 2002, Bandeira et al. 2003, Bandeira \& Vasconcellos 2004, Vasconcellos \& Moura 2014, Araújo et al. 2015, Couto et al. 2015). Studies focusing on termite diversity in montane forests have usually been unable to identify between 24 and $53 \%$ of the morphospecies encountered, indicating the existence of new species and/or taxonomic difficulties (principally related to the subfamily Apicotermitinae). The report here of the genus Acorhinotermes sp. in São Vicente Ferrer is notable, as it is currently considered monospecific (Acorhinotermes subfusciceps) and no records of encounters have yet been published for Brazil. Its current distribution is mainly related to the Amazonian, occurring in Guiana and French Guiana (Emerson 1925, Davies 2002, Davies et al. 2003), and little is known about its biology or ecology. Only one colony of Acorhinotermes sp. was encountered in the decomposing bark of a live tree in the present research.

The species richness of termites in the study areas (15 and $24 \mathrm{spp}$.) were within the amplitude ranges reported for other montane forest areas sampled by several protocols and sampling efforts (between 17 and 29 spp.) (Bandeira \& Vasconcellos 2002, Bandeira et al. 2003, Bandeira \& Vasconcellos 2004, Vasconcellos \& Moura 2014, Couto et al. 2015). In relation to the areas sampled with the same protocol employed in the present study, the numbers of morphospecies reported here were within the amplitude ranges for the studies in the Montane Forests (16 to 29 spp.) (Vasconcellos \& Moura 2014, Couto et al. 2015), in the Atlantic Forest (4 to 34 spp.) (Souza et al. 2012, Cancello et al. 2014); and in the Caatinga domain (7 to 36 spp.) (Mélo \& Bandeira 2004, Vasconcellos et al. 2010, Alves et al. 2011, Vasconcellos \& Moura, 2014).
$\mathbf{A}$

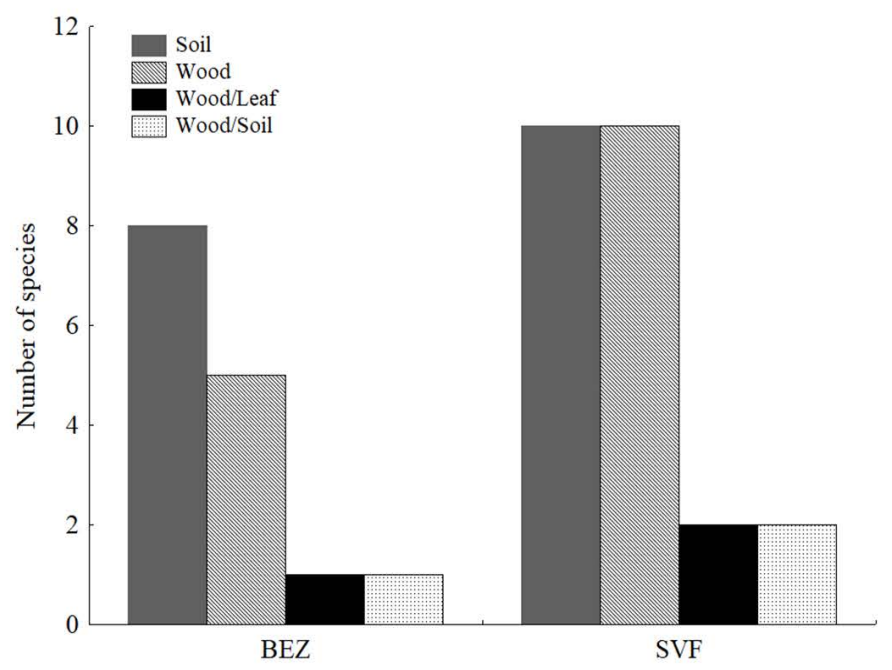

B

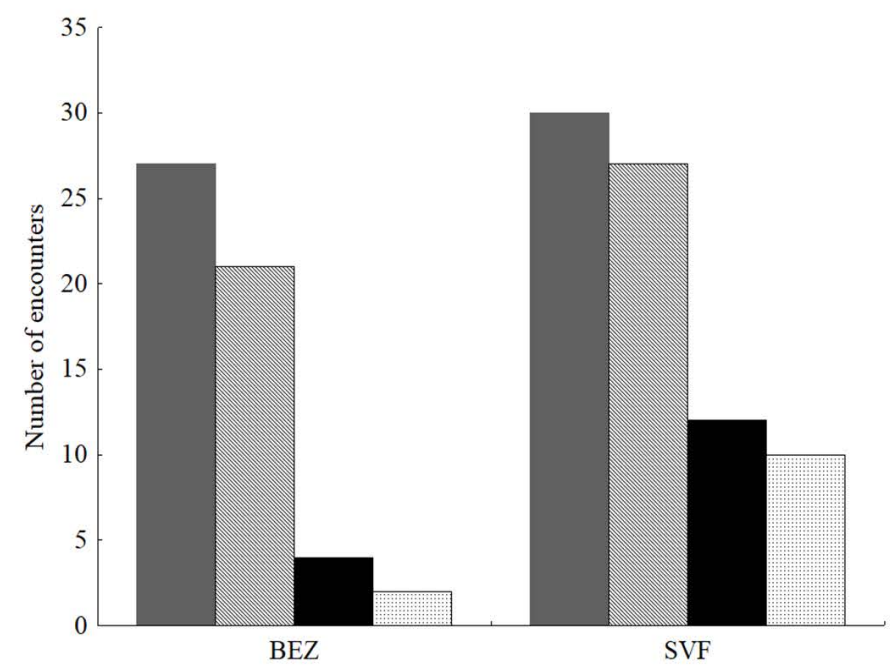

Figure 4. Species richness (a) and numbers of termite encounters (b) per feeding group (category FG1). 
The observed and estimated species richness at Bezerros were relatively similar, indicating sufficient sampling efforts for that site. The richness estimates for São Vicente Ferrer (especially that suggested by the Chao 2 estimator) were larger than the observed richness. This result may be related to the fact that $45.8 \%$ of the species recorded for that area were represented by single sample (uniques). Using the same sampling protocol used in the present study, Cancello et al. (2014) reported that Atlantic Forest remnants in northeastern Brazil demonstrated greater numbers of uniques in relation to Atlantic Forest remnants at higher latitudes, indicating the necessity of greater sampling efforts for rare species at lower latitudes.

In relation to the species richness and abundances of the subfamilies of Termitidae, we found the Apicotermitinae to be predominant in Bezerros while Nasutitermitinae was predominant in São Vicente Ferrer. Previously published studies concerning the termite fauna in montane forests (Bandeira et al. 2003), Atlantic Forests (Reis \& Cancello 2007, Vasconcellos 2010, Souza et al. 2012), and Caatinga sites (Vasconcellos et al. 2010; Viana Junior et al. 2014) have cited the predominance of the subfamily Nasutitermitinae, although Vasconcellos \& Moura (2014) noted variations in the predominance of different subfamilies of Termitidae in montane forests.

In general, the present study encountered greater richness of soil-feeders and wood-feeders termites, respectively, corroborating other studies in similar ecosystems (Bandeira \& Vasconcellos 2002, Bandeira et al. 2003, Vasconcellos \& Moura 2014, Couto et al. 2015). Studies undertaken in humid tropical forests in Brazil (Amazon and Atlantic forests), degraded montane forests, and Caatinga vegetation have reported the predominance of wood-feeders termites (Bandeira et al. 1998, Brandão 1998, Bandeira et al. 2003, Vasconcellos et al. 2005, Reis \& Cancello 2007, Vasconcellos et al. 2010, Souza et al. 2012, Alves et al. 2011, Viana Junior et al. 2014). No previous study undertaken in montane forests used the feeding group classification proposed by Donovan et al. (2001), which may be related to the lack of detailed information available concerning the Neotropical termite fauna (Bandeira et al. 2003). At the global level, soil (group IV) and humus (group III) consumers have been reported to represent the greatest fraction of termites in Humid Tropical Forests in Africa (Cameroon), South America (French Guiana), and Southeast Asia (Borneo) (Davies et al. 2003; Jones \& Eggleton 2011).

Twelve species of termites constructing conspicuous nests are known to inhabit montane forest areas (varying between one and seven species per site) (Bandeira \& Vasconcellos 2002, Vasconcellos $\&$ Moura 2014, Couto et al. 2015). Among those 12 species, only one was encountered in Bezerros and five in São Vicente Ferrer. Their nest densities were greater in São Vicente Ferrer (21.8 nests/ha) than in Bezerros (2.6 nests/ha). Those densities are below published records for the Atlantic Forest (24 to 92.8 nests/ha) (Vasconcellos 2010), but within the amplitude for Caatinga vegetation ( 0.7 to 89 nests/ha) (Martius et al. 1999, Mélo \& Bandeira 2004, Vasconcellos et al. 2010, Alves et al. 2011). The nest density recorded here for São Vicente Ferrer is greater than that reported by Bandeira et al. (2003) in another area of montane forest ( 5 to 10 nests/ha).

In summary, the following findings should be emphasized: (i) as compared to Bezerros, the São Vicente Ferrer site had greater species richness and abundance and higher densities of conspicuous nests, which may be related to factors such as: elevation, climatic variables, levels of anthropogenic disturbances, and/or the sizes of those two areas. The greatest area extension of São Vicente Ferrer can reduce both, the edge effect and the anthropic disturbances on the communities that comprise this ecosystem. Bandeira et al. (2003) consider the effects of environmental degradation and the higher altitude as possible factors resulting in the lower termite diversities observed in montane forests; (ii) was found a greater richness of soil-feeders and wood-feeders termites. Bandeira \& Vasconcellos (2002) report that decrease in species richness of termites, mainly by the reduction of humus and intermediate feeders can associated with levels of environmental disturbance; (iii) although some studies underway in Brazil, new records of species such as the Acorhinotermes sp. are still little known. Thus, the results presented here, combined with data from literature, reinforce need additional studies of the termite fauna in montane forest areas, once the Brejos are currently under high ecological pressure and their preservation is urgent.

\section{Acknowledgments}

The authors would like to thank Emanuelly Félix de Lucena and Cynthia Arielly Alves de Sousa for their help with the fieldwork; the Conselho Nacional de Desenvolvimento Científico e Tecnológico/CNPq for financing this project through a CNPq/Universal 14/2014 (n.461875/20144) grant. AV thanks CNPq for the research grant (proc. 304210/2017-0).

\section{Author Contributions}

Israel Soares da Silva - Substantial contribution in the concept and design of the study; Contribution to data collection; Contribution to data analysis and interpretation; Contribution to manuscript preparation and critical revision, adding intellectual content.

Alexandre Vasconcellos - Substantial contribution in the concept and design of the study; Contribution to data analysis and interpretation; Contribution to manuscript preparation and critical revision, adding intellectual content.

Flávia Maria da Silva Moura - Substantial contribution in the concept and design of the study; Contribution to data collection; Contribution to data analysis and interpretation; Contribution to manuscript preparation and critical revision, adding intellectual content.

\section{Conflicts of interest}

The authors declare that they have no conflict of interest related to the publication of this manuscript.

\section{References}

ALVARES, C.A., STAPE, J.L., SENTELHAS, P.C., GONÇALVES, J.L.M. \& SPAROVEK, G. 2013. Köppen's climate classification map for Brazil. Meteorologische Zeitschrift. 22(6):711-728.

ALVES, W.F., MOTA, A.S., LIMA, R.A.A., BELLEZONI, R. \& VASCONCELLOS, A. 2011. Termites as Bioindicators of Habitat Quality in the Caatinga, Brazil: Is There Agreement Between Structural Habitat Variables and the Sampled Assemblages? Neotrop. Entomol. 40(1):39-46.

ANDRADE-LIMA, D. 1982. Present day forest refuges in Northeastern Brazil. In Biological Diversification in the Tropics (Prance, G.T., ed.), Columbia University Press, New York, p.245-254.

ANDRADE-LIMA, D. 1960. Estudos fitogeográficos de Pernambuco. Arq. Inst. Pesq. Agron. 5:305-341. 
ANDRADE-LIMA, D. 1966. Esboço fitoecológico de alguns "Brejos" de Pernambuco. Boletim Técnico. Inst. Pesq. Agron. 8:3-9.

ANDRADE-LIMA, D. 2007. Estudos fitogeográficos de Pernambuco. Anais da Academia Pernambucana de Ciência Agronômica. Recife, 4:243-274.

APAC, Agência Pernambucana de Águas e Clima. 2017. Monitoramento pluviométrico 2016. http://www.apac.pe.gov.br/meteorologia/ monitoramento-pluvio.php?posto_id=271. (Acessed on 16/Ago/2017).

ARAÚJO, V.F.P., SILVA, M.P. \& VASCONCELLOS, A. 2015. Soil-sampled termites in Two Contrasting Ecosystems within the Semiarid Domain in Northeastern Brazil: Abundance, Biomass, and Seasonal Influences, Sociobiol. 62(1):70-75.

BANDEIRA, A.G., PEREIRA, J.C.D., MIRANDA, C.S. \& MEDEIROS, L.G.S. 1998. Composição da fauna de cupins (Insecta, Isoptera) em área de Mata Atlântica em João Pessoa, Paraíba, Brasil. Rev. Nord. Biol. 12(1/2):9-17

BANDEIRA, A.G. \& VASCONCELLOS, A. 2002. A quantitative survey of termites in a gradient of disturbed highland forest in Northeastern Brazil. Sociobiol. 39(3):429-439.

BANDEIRA, A.G., VASCONCELLOS, A., SILVA, M.P. \& CONSTANTINO, R. 2003. Effects of habitat disturbance on the termite fauna in a highland forest in the Caatinga domain, Brazil. Sociobiol. 42(1):117-127.

BANDEIRA, A.G. \& VASCONCELlOS, A. 2004. Efeitos de Perturbações Antrópicas sobre as Populações de Cupins (Isoptera) do Brejo dos Cavalos, Pernambuco. In Brejos de altitude em Pernambuco e Paraíba: história natural, ecologia e conservação (Porto, K.C., Cabral, J.J.P. \& Tabarelli, M., ed.), Ministério do Meio Ambiente, Brasília, p.145-152.

BIGNELL, D.E. \& EGGLETON, P. 2000. Termites in ecosystems. In Termites: Evolution, Sociality, Symbiosis, Ecology (Abe, T., Higashim \& Bignell, D.E., ed.), Kluwer Academic Publications, Dordrecht, p.363-387.

BORGES-NOJOSA, D.M. \& CARAMASCHI, U. 2003. Composição e Análise Comparativa da Diversidade e das Afinidades Biogeográficas dos Lagartos e Anfisbenídeos (Squamata) dos Brejos Nordestinos. In Ecologia e Conservação da Caatinga (I. Leal, J.M.C. Silva \& M. Tabarelli, ed.). UFPE, Recife, p.489-540.

BOURGUIGNON, T., SCHEFFRAHN. R.H., NAGY, Z.T., SONET, G., HOST, B. \& ROISIN, Y. 2016. Towards a revision of the Neotropica soldierless termites (Isoptera: Termitidae): redescription of the genus GrigiotermesMathews and description of five new genera. Zoological Journal of the Linnean Society 2176:15-35.

BRANDÃO, D. 1998. Patterns of termite (Isoptera) diversity in the Reserve Florestal de Linhares, state of Espírito Santo, Brazil. Rev. Bras. Entomol. 41:151-153.

CANCELLO, E.M., SILVA, R.R., VASCONCELLOS, A., REIS, Y.T. \& OLIVEIRA, L.M. 2014. Latitudinal variation in termite species richness and abundance along the Brazilian Atlantic Forest Hotspot. Biotropica. 46:441- 450.

CARNAVAL, A.C.O.Q. 2002. Phylogeography of four frog species in forest fragments of northeastern Brazil - a preliminary study. Integrative and Comparative Biology. 42:913-921.

CARNAVAL, A.C.O.Q. \& BATES, J.M. 2007. Amphibian DNA shows marked genetic structure and tracks Pleistocene climate change in northeastern Brazil. Evolution. 61-12:2942-2957.

COLWELL, R.K. EstimateS: Statistical estimation of species richness and shared species from samples. Versão 8. 2005. http://purl.oclc.org/estimates. (Acessed on 12/Jul/2017).

CONSTANTINO, R. 1998. Catalog of the living termites of the New World (Insecta: Isoptera). Arquivos de Zoologia, v.35, n.2, p.135-230.

CONSTANTINO, R. 1999. Chave ilustrada para a identificação dos gêneros de cupins (Insecta: Isoptera) que ocorrem no Brasil. Papéis Avulsos de Zoologia. 40:387-448.

CONSTANTINO, R. 2002. An illustrated key to Neotropical termite genera (Insecta: Isoptera) based primarily on soldiers. Zootaxa, v.67, p.1-40.

CONSTANTINO, R. 2017. On-line termite database. http://vsites.unb.br/ ib/ zoo/catalog.html. (Acessed on 9/Jun/2017).
COUTO, A.A.V.O., ALBUQUeRQUe, A.C., VASCONCELlos, A. \& CASTRO, C.C. 2015. Termite assemblages (Blattodea: Isoptera) in a habitat humidity gradiente in the semiarid region of northeastern Brazil. Zoologia. 32(4):281-288.

DAVIES, R.G. 2002. Feeding group responses of a Neotropical termite assemblage to rain forest fragmentation. Oecologia. 133: 233-242.

DAVIES, R.G., EGGLETON, P., JONES, D., GATHORE-HARDY, F. \& HERNÁNDEZ, L.M. 2003. Evolution of termite functional diversity: analysis and synthesis of local ecological and regional influences on local species richness. Journal of Biogeography. 30:847-877.

DCA, Departamento de Ciências Atmosféricas. Dados Climatológicos do Estado de Pernambuco. 2016. http://www.dca.ufcg.edu.br/clima/dadospe.htm. (Acessed on 20/Sep/2017).

DE SOUZA, O.F.F. \& BROWN, V.K. 1994. Effects of habitat fragmentation on Amazonian termite communities. Journal of Tropical Ecology. 10:197-206.

DONOVAN, S.E., EGGLETON, P. \& BIGNELL, D.E. 2001. Gut content analysis and a new feeding group classification of termites. Ecol. Entomol. 26:356-366.

EGGLETON, P. 2000. Global patterns of termite diversity. In: Termites: Evolution, Sociality, Symbiosis, Ecology (Abe, T., Higashi, M. \& Bignell, D.E., ed.), Kluwer Academic Publications, Dordrecht, p.25-51.

EMERSON, A.E. 1925. The termites from Kartabo, Bartica District, Guyana. Zoologica, v.6, 4:291-459.

HOLT, J.A. \& LEPAGE, M. 2000. Termites and soil properties. In Termites: evolution, sociality, symbioses, ecology (Abe, T., Bignell, D.E. \& Higashi, M., ed.), Kluwer Academic Publishers, Dordrecht, p.389-407.

JONES, D.T. \& EGGLETON, P. 2011. Global Biogeography of Termites: A Compilation of Sources. In Biology of Termites: a Modern Synthesis (Bignell, D. E., Roisin, Y. \& Lo, N., ed.), Springer Netherlands, Germany, p.477-498.

JONES, D.T. 2000. Termite assemblages in two distinct montane forest types at $1000 \mathrm{~m}$ elevation in the Maliau Basin, Sabah. Journal of Tropical Ecology. 16:271-286.

JONES, D.T. \& EGGLETON, P. 2000. Sampling termite assemblages in tropical forests: testing a rapid biodiversity assessment protocol. Journal of Applied Ecology, Oxford. 37:191-203.

KÖPPEN, W. 1936. Das geographische system der klimate. In Handbuch der Klimatologie, part C. (Köppen, W. \& Geiger, R. ed.). Verlag von Gebrüder Borntraeger, Berlin, p.1-44.

LEAL, I.R., SILVA, J.M.C., TABARELLI, M. \& LACHER, J.R.T.E. 2005. Changing the course of biodiversity conservation in the Caatinga of northeastern Brazil. Conservation Biology. 19(3):701-706.

MARTIUS, C., TABOSA, W.A.F., BANDEIRA, A.G. \& AMELUNG, W. 1999. Richness of termite genera in a semi-arid region (Sertão) in NE Brazil. Sociobiol. 33:357-365.

MÉLO, A.C.S. \& BANDEIRA, A.G. 2004. A qualitative and quantitative survey of termites (Isoptera) in an open shrubby Caatinga in Northeast Brazil Sociobiol. 44(3):707-716.

NUNES, C.A., QUINTINO, A.V., CONSTANTINO, R., NEGREIROS, D., JUNIOR, R.R. \& FERNANDES, G.W. 2017. Patterns of taxonomic and functional diversity of termites along a tropical elevational gradient. Biotropica. 49(2): 186-194.

PRADO, D.E. 2003. As caatingas da América do Sul, p. 3-74. In Ecologia e conservação da Caatinga. (Leal, I. R, Tabarelli, M. \& Silva, J.M.C., ed.) Editora Universitária, Universidade Federal de Pernambuco, Recife, 822p.

REIS, Y.T. \& CANCELLO, E.M. 2007. Riqueza e diversidade de cupins (Insecta, Isoptera) numa área de mata primária e outra secundária, na Mata Atlântica do sudeste da Bahia. Iheringia, Série Zoologia. 97:229-234.

RODAL, M.J.N. \& SALES, M.F. 2008. Panorama of the Montane Forests of Pernambuco, Brazil. In The Atlantic Coastal Forest of Northeastern Brazil (Thomas W.W., ed.), The New York Botanical Garden, Bronx, New York, p.541-559.

SANTOS, A.M.M., CAVALCANTI, D.R., SILVA, J.M.C. \& TABARELLI, M. 2007. Biogeographical relationships among tropical forests in northeastern Brazil. Journal of Biogeography. 34:437-446. 
SEMAS, Secretaria de Meio Ambiente e Sustentabilidade. 2014. Proposta para criação de Unidades de Conservação na Mata de Siriji, em São Vicente Ferrer - PE. 50p.

SENA, J.M., VASCONCELLOS, A., GUSMÃO, M.A.B. \& BANDEIRA, A.G. 2003. Assemblage of termites in a fragment of cerrado on the coast of Paraiba State, Northeast Brazil (Isoptera). Sociobiol. 42(3)753-760.

SILVA, J.M.C., LEAL I. \& TABARELLI, M. 2018. Caatinga: the largest tropical dry forest region in South America. Springer, New York.

SOUZA, H.B.A., ALVES, W.F. \& VASCONCELLOS, A. 2012. Termite assemblages in five semideciduous Atlantic Forest fragments in the northern coastland limit of the biome. Rev. Bras. Entomol. 56(1):67-72.

TABARELLI, M. \& SANTOS, A.M.M. 2004. Uma Breve Descrição Sobre a História Natural dos Brejos Nordestinos. In Brejos de altitude em Pernambuco e Paraíba: história natural, ecologia e conservação (Porto, K.C., Cabral, J.J.P. \& Tabarelli, M., ed.), Ministério do Meio Ambiente, Brasília, p.17-24.

TAVARES, M.C.G., RODAL, M.J.N., MELO, A.L. \& ARAÚJO, M.F. 2000. Fitossociologia do componente arbóreo de um trecho de Floresta Ombrófila Montana do Parque Ecológico João Vasconcelos - Sobrinho, Caruaru, Pernambuco. Naturalia, v. 25, p.17-32.

VASCONCELLOS, A. 2010. Biomass and abundance of termites in three remnant areas of Atlantic Forest in northeastern Brazil. Rev. Bras. Entomol. 54(3):455-461.

VASCONCELLOS, A., MÉLO, A.C.S., SEGUNDO, E.M.V. \& BANDEIRA, A.G. 2005. Cupins de duas florestas de restinga do Nordeste Brasileiro. Iheringia, Série Zoologia. 95:127-131.
VASCONCELLOS, A. \& MOURA, F.M.S. 2014. Térmitas de Oito Ecossistemas Inseridos no Domínio do Semiárido Brasileiro. In Artrópodes do Semiárido: Biodiversidade e Conservação. (Bravo, F. \& Calor, A., ed.). Printmidiap, Feira de Santana, p.99-109.

VASCONCELLOS, A., BANDEIRA, A.G., MOURA, F.M.S., ARAÚJO, V.F.P., BEZERRA-GUSMÃO, M.A. \& CONSTANTINO, R. 2010. Termite assemblages in three habitats under different disturbance regimes in the semi-arid Caatinga of NE Brazil. J. Arid Environ. 74:298- 302.

VELOSO, H.P., RANGEL-FILHO, A.L.R. \& ANDRADE-LIMA, D. 1991. Classificação da Vegetação Brasileira, Adaptada a um Sistema Universal. Departamento de Recursos Naturais e Estudos Ambientais, Instituto Brasileiro de Geografia e Estatística, Rio de Janeiro.

VELOSO, H.P. \& GÓES FILHO, L. 1982. Fitogeografia brasileira classificação fisionômico-ecológica da vegetação neotropical. Boletim Técnico, Série Vegetação 1.

VIANA JUNIOR, A.B., SOUZA, V.B., REIS, Y.T. \& MARQUES-COSTA, A.P. 2014. Termites assemblages in the Caatinga of Brazil. Sociobiol. 61(3):324-331.

WOOD, T.G. \& SANDS, W.A. 1978. The role of termites in ecosystems. In Production Ecology of Ants and Termites (Brian, M.V., ed.), Cambridge University Press, Cambridge, p.245-292.

Received: $24 / 01 / 2018$

Revised: $27 / 11 / 2018$

Accepted: 11/12/2018

Published Online: 24/01/2019 